\title{
Investigation of the Effects of Smart Ultrasound Wave on Surface Roughness during Turning Operation of Mild Steel
}

Anayet Ullah Patwari, Md. Shariful Islam Chowdhury, Mohammad Ahsan Habib, Afzal Hossain Neelav, Md. Sharfat Latif, T. M. Moniruzzaman Sunny

Department of Mechanical and Chemical Engineering, Islamic University of Technology (IUT), Dhaka, Bangladesh Email: aupatwari@hotmail.com, shemon00@gmail.com, m.ahsan.habib@gmail.com, neelav.hellboy@gmail.com, sejan101411@gmail.com,tmmsunny@gmail.com

Turning is one of the most widely accepted metal cutting processes in manufacturing industry. Due to global competitiveness, there is an increasing demand for product quality. Surface roughness represents the dimensional accuracy of the finished product and is one of the most important quality requirements of the finished product. Surface roughness is generally detrimental to the efficient performance of machined parts, especially where relative motion between parts is concerned. In this paper, a new novel technique has been proposed and adopted with an aim to reduce surface roughness of the machined surface. External ultrasonic sound waves were applied during the turning process of mild steel and its effect on surface quality was studied. Detailed experimentations were carried out under different ultrasonic frequencies to determine the effective frequency range which optimizes surface roughness to the best degree possible. The experimental results showed significant improvements in surface roughness in machined products. In addition to these, the effect of orientation of the application of the ultrasonic sound waves and the amplitude of the waves were studied in detail.

Keywords: Ultrasound, Surface Roughness, Vibration, Orientation, Amplitude

\section{References}

[1] KALPAKJIAN, S., SCHMID, S.R. (2009) Manufacturing Processes for Engineering Materials, In: 5th ed., India: Dorling Kindersley Pvt. Ltd. (under license from Pearson Education in South Asia), pp. 440-447.

[2] CePOVA, L., SOKOVA, D., MALOTOVA, S., GAPINSKI, B., CEP, R. (2016). Evaluation of Cutting Forces and Surface Roughness after Machining of Selected Material. In: Manufacturing Technology, Vol. 16, No. 1, pp. 45-48.

[3] BAČA, A., KONEČNÁ, R., NICOLETTO, G., KUNZ, L. (2015). Effect of Surface Roughness on the Fatigue Life of Laser Additive Manufactured Ti6Al4V Alloy. In: Manufacturing Technology, Vol. 15, No. 4, pp. $498-502$.

[4] HRICOVA, J., NAPRSTKOVA, N. (2015). Surface Roughness Optimization in Milling Aluminium Alloy by Using the Taguchi's Design of Experiment. In: Manufacturing Technology, Vol. 15, No. 4, pp. 541-546.

[5] SIlbERSChMidTA, V. V, MAHDYB, S. M. A., GOUDAB, M. A., NASEERA, A., AGOSTINO MAUROTTOA, A. ROYA, A. (2014). Surface-roughness improvement in ultrasonically assisted turning. In: $2 n d$ CIRP Conference on Surface Integrity (CSI), Procedia CIRP, Vol. 13, pp. 49 - 54.

[6] MAHDY, S. M. A., GOUDA, M. A., SILBERSCHMIDT, V. V. (2013). Study of ultrasonically assisted turning of stainless steel and brass alloys. In: Journal of Physics: Conference Series 451, paper 012037.

[7] MUHAMMAD, R., MAUROTTO, A., ROY, A., SILBERSCHMIDT, V. V. (2012). Ultrasonically assisted turning of Ti-6Al-2Sn-4Zr-6Mo. In: Journal of Physics: Conference Series 382, paper 012016.

[8] RIMKEVIČIENĖ, J., OSTAŠEVIČIUS,V., JŪRĖNAS, V., GAIDYS, R. (2009). Experiments and simulations of ultrasonically assisted turning tool. In: MECHANIKA, ISSN 1392 - 1207, Volume 1, No. 75.

[9] MAUROTTO, A., MUHAMMAD, R., ROY, A., SILBERSCHMIDT, V. V. (2013). Enhanced ultrasonically assisted turning of a $\beta$-titanium alloy. In: Ultrasonics 53, pp. 1242.

[10] PATIL, S., JOSHI, S., TEWARI, A., JOSHI, S. S. (2014). Modelling and simulation of effect of ultrasonic vibrations on machining of Ti6Al4V. In: Ultrasonics, Vol. 54, No. 2, pp. 694-705.

[11] EZE, S.C., IZELU, C.O., OREKO, B.U., EDWARD, B.A. (2013). Experimental Study of Induced Vibration and Work Surface Roughness in the Turning of 41Cr4 Alloy Steel using Response Surface Methodology. In: International Journal of Innovative Research in Science, Engineering and Technology, ISSN: 2319-8753, Vol. 2, No. 12.

[12] KUMAR, K.A., RATNAM, C., MURTHY, B.S.N., BEN, B.S., REDDY, K.R.R.M. (2012). Optimization of Surface Roughness in Face Turning Operation in Machining Of En-8. In: International Journal of Engineering Science \& Advanced Technology, ISSN: 2250-3676, Vol. 2, No. 4, pp. $807-812$. 
[13] RODRIGUES, L.L.R., KANTHARAJ, A.N., KANTHARAJ, B., FREITAS, W.R.C., MURTHY, B.R.N. (2012). Effect of Cutting Parameters on Surface Roughness and Cutting Force in Turning Mild Steel. In: Research Journal of Recent Sciences, ISSN 2277-2502, No. 10, pp. 19-26.

[14] REDDY, B.S., PADMANABHAN, G., REDDY, K.V.K. (2008). Surface Roughness Prediction Techniques for CNC turning. In: Asian Journal of Scientific Research, Vol. 1, No. 3, pp. 256-264.

[15] THAMMA, R. (2008). Comparison between Multiple Regression Models to Study Effect of Turning Parameters on the Surface Roughness. In: Proceedings of the 2008 IAJC-IJME International Conference, ISBN 978-1-60643379-9, Paper 133, ENG 103, pp. 1-12.

\section{Paper number: M2016142}

Copyright (C) 2016. Published by Manufacturing Technology. All rights reserved. 